\title{
Classroom Assessment
}

\author{
[A short Communication] \\ Angela Khristin Brown
}

E-mail: brownlas6@aol.com

Doi:10.7575/aiac.alls.v.5n.1p.21

Received: 08/01/2014

URL: http://dx.doi.org/10.7575/aiac.alls.v.5n.1p.21

Accepted: 22/02/2014

The importance of benefiting with a top notch education depends on the value of presentation of the lesson offered. A good instructor will develop his/her curriculum on the basis of the academic performance of his/her students. A good instructor knows how to manipulate speech to develop a positive communication to his/her students. A lack of communication will result from an inactive audience. An educational climate is the key to determining the learning progress in a class.

The curriculum in a classroom should have modern technology. Imagine gathering the attention from every student. A student's progress is mediated with how an instructor verbally communicates through action. The usage of modern technology in the classroom will improve a student's academic performance. Replace the pen and pad with a lap tap to understand how to improve comprehension in the classroom. No longer shall an instructor teach on a monitor; but, to use the internet, PowerPoint, word, excel explanation from a key pad and observe the student's progress.

Library technology is an intricate method every student needs to conduct research. Viable research is conducted on the web. With the proper training to write a academic paper, a student can research accredited magazines, news articles, journal articles, books, references, citations that are accurate and current. With the right technology, an instructor can apply track changes to correct a student paper. An instructor can run any student's paper through library resources to verify how plagiarized a student's paper is. Academic research can be used in subjects like business, science, literature, etc. Once the students learn how to manipulate words, communication will improve his/her writing performance.

This is the "media age" generation through the advancement of computer technology. Test can be taken on smart phones. I pads can be used to download ebooks. Note books can be used to take class notes. The instructor can use the internet to project a movie or presentation. Modern technology can be used towards an instructor's advantage as a tool to communicate a "learning experience." This is the "digital age." We must use it to our advantage.

We are the environment that surrounds us. Progress is what mediates our learning climate. If we take advantage of progress, students will adapt to learn the skills necessary to transcend in the next learning generations to come. By using technology, we are dictating our future performance to outsource other nations. It all started with a simple "idea" an it is with that idea that made a difference by touching a life. 